Ethiopian Journal of Environmental Studies \& Management 8(1): 1 - 12, 2015.

ISSN:1998-0507

doi: http://dx.doi.org/10.4314/ejesm.v8i1.1

Submitted: June 07, 2014

Accepted: January 03, 2015

\title{
A SURVEY OF RELIABILITY OF TILLAGE EQUIPMENT IN OSUN STATE, NIGERIA
}

\author{
*OLAOYE, J.0.1 AND ADEKANYE, T.A. ${ }^{2}$ \\ ${ }^{1}$ Department of Agricultural and Biosystems Engineering, University of Ilorin, Nigeria \\ ${ }^{2}$ Department of Agricultural Engineering, Landmark University, Omuaran, Nigeria
}

\begin{abstract}
Reliability of tillage equipment in Osun State, Nigeria was investigated by using Weibull function. Frequencies of breakdown and time of failure of the implements were collected and analyzed using Weibull method. Results obtained showed that harrows were the most reliable followed by ridger and the plough respectively. Disc blade, disc gang and bearing failed in use while other components show no fault. The study showed that actual efficiency of operation was very low compared to the theoretical efficiency designed by the manufacturer. Theoretical efficiency of plough, harrow and ridger were 46\%, 22\% and 71\% respectively. Overall Weibull parameters for plough were $\left(\alpha=28.49\right.$ and $b=6.0$ with $t_{50}=$ 26.85), for harrow, the disc blade had the highest parameters of $\alpha=22.36$ and $B=8.80$ with $t_{50}=21.45$ but the bearing showed the least $\alpha=11.47, b=9.30$ and $t_{50}=11.03$. Overall harrow parameters were $\left(\alpha=22.42, b=8.30\right.$ and $\left.t_{50}=21.45\right)$. Mast and spacer spool showed no faults at all. The top link hitch point had the highest parameters of $\alpha=93.36, \beta=5.35$ and $t_{50}=87.49$. The least $\alpha$ parameter was 'bearing' with $\alpha=14.54,6=1.04$ and $t_{50}=10.22$. Overall ridger parameters were $\left(\alpha=24.29, \beta=6.0\right.$ and $\left.t_{50}=22.81\right)$. Harrow showed low incidence of breakdown, hence, it was more reliable than ridger and plough. Variation in the theoretical and actual field efficiency and capacity were due to many factors such as travel time to the field, down time on the field and competence level of operator, terrain, soil conditions and vegetation as most of the implements were designed to suite working conditions of the temperate countries. Repair and maintenance of facilities affected the reliability of the implements. Lack of genuine spare parts, few or lack of special repair and maintenance tools and improper record keeping habits account for the observed reliability. Efficiencies of these implements were affected by the period of operation per day, speed of operation and effective width of implements.
\end{abstract}

Key Words: Tillage, equipment, reliability, Soil conditions, Implement breakdown

\section{Introduction}

Tillage is an operation to improve soil conditions for optimal crop emergence and yield. Tillage is a very time specific operation, and efficient management of this system is essential for maximizing crop production (Lal, 1997; Lal, 1987). The choice of tillage methods are dictated by the soil and precipitation pattern, cropping system and amount of crop residue said (Ofori, 1995). The compromise must be established between using a reliable equipment for carrying out timely tillage operations with well maintain tillage implements. Tillage problems have been attributed to the transfer of technology from 
one ecological region to another without the consideration of soil, environmental and socio economic factors said (Hartman, 1983). In Africa, there are many examples of farm projects, which have failed due to ill adapted tillage techniques and inappropriate equipment. Reliability is the probability that an implement will complete a specific task under specified conditions for a stated period of time (Archer, 1963; Hunt, 1971). It is a mathematical expression of likelihood of satisfactory operation (Ishola and Adeoti, 2004). Failure may be referred to as any condition, which prevents operation of a machine or implement, to result in a low level of performances. It is essential that the operational life of the implement is as long as possible. Tillage implement is to ensure timeliness of agricultural operation. Tillage operations must carried out at appropriate time (Wingate - Hill, 1981). The tillage operations must be done to ensure that seedbed of good tilt is obtained; weeds are destroyed to prevent their growth, add humus and fertility to the soil by covering vegetation and manure; leave the soil in a condition to retain moisture from rain; and to obtain optimum field capacity and efficiency of implements without unnecessary stoppage.

Breakdown is a form of mechanical failure in equipment. It is the collapse of tillage equipment during operation. Breakdown introduces some problems which include: delay in operation due to long stoppage time; it brings about increase in maintenance cost and operational cost; it affects the efficiency of the implement and difficulty in repair on the field; and breakdown increases the labour cost, transport, and subsistence allowance of workers. Frequency of breakdown of equipment and high cost of purchasing new ones demand effective management of farming implements. There are various models and makes of farm implement in use in Nigeria with different degree of level of breakdown and effectiveness on diverse soil conditions (Olaoye, 2007).

Farmers are rarely aware of the level of dependability of the working tools been moved to the field for farm operations. In most cases operators are not prepared for the un-imaginable eventuality as occasioned by tillage break down. Time loss occurred in movement of working implements to the workshop where appropriate repair tools may not be available during maintenance operation on the field. This study was carried out to investigate nature of breakdown, time between failures of tillage equipment. The main objective of this study is to establish the influence of maintenance, capacity and reliability of component of tillage implements on the overall performance of tillage operation. The specific objective is to examine machine settings and adjustment on tillage implement during operation with respect to component reliability.

\section{Materials and Methods \\ Description of the Study Area}

This study was conducted in Osun State, Nigeria. The State has an area of 14, $875 \mathrm{~km}^{2}$, a population of about $3,423,535$ people (National Population Commission, 2010). It is bounded in the north by Kwara State, in the east by Ekiti and Ondo States, in the south by Ogun State and in the west by Oyo State. The area is located between latitude $7^{\circ} 30^{\prime} 0^{\prime \prime} \mathrm{N}$ and longitude $4^{\circ} 300 \mathrm{E}$. It is endowed with tropical rain forest vegetation on a plain terrain with patches of rivers and streams. The occupation of the people of the State is primarily farming. 
They produce food crops as well as cash crops. This research was carried out using participant observations, on spot assessment and interview schedule. Procedure stated by Dhudsia (1992) was also adopted.

\section{Tillage Equipment}

Materials for the study include tillage equipment and materials for measurement of soil characteristics. Tillage implements are used for mechanical disturbance of the soil to make soil suitable for plant growth and they include plough, harrow and ridger. A total of representative fifteen ploughs, seven Harrow and seven ridgers were investigated. Each representative sample represents mean of twelve data size for each implement. The entire implements surveyed were serviceable and had covered operational periods ranging from twenty four (24) to twenty-six (26) months. The entire implements surveyed were serviceable and had covered operational periods ranging from twenty - four (24) to twenty-six (26) months.

\section{Soil Characteristics}

The prevailing soil conditions of the study area were characterized by hard soil condition where moisture ranged between $18 \%-21 \%$ moisture content. The soil condition can be moulded into appropriate shape and the soil pores are filled with water. Augers were used to obtain undisturbed soil cores at different depths. The method described by Kumar and Mittal (2008) was used to evaluate the soil moisture characteristic.

\section{Sampling Techniques}

A reliability survey was conducted in fifteen (15) local government areas of the State. The reliability of these implements depends on usage and maintenance practice on the implements. This survey was conducted in order to obtain various parameters for the reliability of each component of the implements. A quantified reliability of the components was carried out on the time to failure of the components. This research was carried out using participant observation, on spot assessment and interview schedule. The data obtained was compiled and analyzed by using Weibull distribution function as shown in equation 1.

$\mathrm{R}(\mathrm{t})=1-\exp \left[-\frac{t}{\alpha}\right]^{\beta}$

where;

$\mathrm{b}=$ location parameter and tends to zero

$\mathrm{R}(\mathrm{t})=$ Reliability (in percentage)

$\mathrm{t}=$ Time between failure

$\alpha=$ Weibull scale parameter

$\beta=$ Weibull shape or slope parameter

The median rank equation and regression analysis equation used in conjunction with the weibull model were used to evaluate the weibull parameters $(\alpha, \beta)$ to obtain analysis made with the time to failure. This procedure compares with Rutter (2009).

\section{Commutative Distribution}

The cumulative failure distribution function is determined using equation (2). Relationship between reliability and maintenance in terms of implement variables or characteristics was investigated using Weibull function (Equations 1 and 3). But equation (2) relates the failure rate, $1 / \lambda$ to the Mean Time Before Failure, MTBF that is defined as the ratio of total operating hour of an item to the total number of failure that occur while the equipment is been used. Multi-linear repair and maintenance cost models were used by ALSuhaibani (1996) but could not measure the reliability of various components of the machine implements.

$F(t)=1-\exp (-\lambda t c)$ 
where;

$$
\begin{aligned}
& \mathrm{F}(\mathrm{t})=\text { cumulative failure distribution } \\
& \text { function } \\
& \mathrm{T}=\text { time between successive failure } \\
& \lambda=\text { scale parameter }=\lambda=\frac{1}{M T B F} \\
& \mathrm{c}=\text { shape parameter. }
\end{aligned}
$$$$
\mathrm{R}(\mathrm{t})=\exp -[(\mathrm{t}-\gamma) / \alpha]^{\beta}
$$

where;

$(\gamma, \beta, \alpha)$ are parameters related to physical meaning in quite way does failure rate. They are parameter which the computation of Reliability and MTBF.

In a special case;

$$
\begin{aligned}
& \mathrm{R}=\mathrm{o}, \beta=1 \\
& \mathrm{R}(\mathrm{t})=\exp [-(\mathrm{t} / \alpha) 1] \\
& \operatorname{Exp}[-\mathrm{t} / \mathrm{n}] \\
& \mathrm{n}=\text { mean time between failure }
\end{aligned}
$$

In general case

$\mathrm{t}=\mathrm{MTBF}$ but it is the scale parameter.

$$
\beta=\text { shape parameter and describe }
$$
the rate of change of failure rate.

$$
\gamma=\text { location parameter }
$$

Weibull expression can be reduced to a straight line equation by taking logarithm twice (Okah - Avae (1996)). The threeweibull parameters are obtained by straight line and hence express the reliability through the slope and intercept. $(\gamma=0, \beta=$ $1.5 \mathrm{n}=\mathrm{t}$ for $\mathrm{O}(\mathrm{t})=0.63$ )

The time between successive failure data for each component of the implement make shall be a analyzed to obtain the weibull parameters $(\beta, \alpha)$ and the time between failure at a set reliability of each component (Kapur and Lamberson, 1977). The data for each component of the implement irrespective of the make was analyzed to obtain the overall weibull parameters and overall time failure at a set reliability of the component. Likewise the weibull parameter and the time at a set reliability of each implement as a whole were also obtained.

Field efficiency: is the ratio of the effective field capacity to theoretical field capacity, expressed in percentage (Equation 4).

$\mathrm{y}_{\mathrm{f}}=\mathrm{C}_{\mathrm{af}} / \mathrm{C}_{\mathrm{tf}} \mathrm{X} 100 \%$

where;

$\mathrm{y}_{\mathrm{f}}=$ field efficiency,

$\mathrm{C}_{\mathrm{af}}=$ actual field capacity and

$\mathrm{C}_{\mathrm{tf}}=$ theoretical field capacity.

Field capacity: is the actual rate of land processed or tilled in a given time. F.C = hectare $/ \mathrm{hr}$

Theoretical field capacity: is the rate of performance obtained if a machine performs its function $100 \%$ of the time at a given operating seed using $100 \%$ of its theoretical width

Effective field capacity: is a function of speed, machine working width, field efficiency and unit yield of the field. Area capacity is expressed in equation 5.

$\mathrm{Ca}=\mathrm{swE}_{1} / 10$

where;

$\mathrm{Ca}=$ Area capacity, ha/hr, s=speed $(\mathrm{km} / \mathrm{hr}$.)

$\mathrm{w}=$ implement working width $(\mathrm{m}), \mathrm{E}_{1}=$ field efficiency

Field speed: is the average rate of machine travel in the field eluding an uninterrupted period of function activity. For instance raising an implement out of the soil would affect the functional activity of the implement. Field speed $=$ distance cover /time taken

For tillage equipment each has it its own operating speed.

Draft: is described as force required in the horizontal direction of travel. Draft force required to pull minor tillage implement operated at shallow depth, is a primary function of the width of the implement and 
the speed of pull. Typical draft can be calculated as presented in equation (6).

$\mathrm{D}=\mathrm{F}(\mathrm{A}+\mathrm{B}) \mathrm{s}+\mathrm{C} \mathrm{s}^{2} \mathrm{WT}$

where;

$\mathrm{A}, \mathrm{B}, \mathrm{C}=$ parameters constant

$\mathrm{F}=$ soil texture adjustment parameter

$\mathrm{D}=\operatorname{draft}(\mathrm{N})$

$\mathrm{s}=$ speed $(\mathrm{km} / \mathrm{hr}$.)

$\mathrm{W}=$ machine width $(\mathrm{m})$,

$\mathrm{T}=$ tillage depth $(\mathrm{cm})$

Disc setting is the adjustment of the tillage implement in preparation for field operation. Tilt angle of disc is related to the vertical angel between $15^{\circ}$ and $25^{\circ}$ for plough. It affects the penetration of the plough and greatest when closet to vertical. Disc angle or angle of attack: is the angle, which lies between the disc force and the direction of travel. Depth of cut it is a function of the type of crop to be planed it is a measure of the height of furrow made by the implement.

\section{Results and Discussion}

\section{Implement Performance Evaluation}

Tables 1 to 3 show the performance evaluation of the tillage equipment (plough, harrow and ridger) respectively. These tables show that the efficiencies of these implements are affected by the period of operation per day, the speed of operation and the effective width of the implements. This observation collaborates with the findings of Abdelmotaleb (1993), Konda and Larson (1990), Inns (1978) and Rotz (1987). The expected efficiency ranges from (79-92) \% for plough with an average efficiency of $88 \%$ while the actual efficiency ranges between (28-65) \% with an average of $46 \%$. The field speed for plough is between $9.0 \mathrm{~km} / \mathrm{hr}-10.5 \mathrm{~km} / \mathrm{hr}$ with an average of $9.87 \mathrm{~km} / \mathrm{hr}$. The average width of cut is between $0.24 \mathrm{~m}-5.00 \mathrm{~m}$ with an average of $0.33 \mathrm{~m}$. The working hour per day is about $8 \mathrm{hrs}$. The theoretical capacity $\mathrm{C}_{\mathrm{t}}(\mathrm{ha} / \mathrm{hr})$ is between $0.68 \mathrm{ha} / \mathrm{hr}-$ $1.50 \mathrm{ha} / \mathrm{hr}$ with an average of about $0.97 \mathrm{ha} / \mathrm{hr}$ while the effective field capacity is between $0.38 \mathrm{ha} / \mathrm{hr}-0.49 \mathrm{ha} / \mathrm{hr}$ with an average of $0.42 \mathrm{~m}$. Wahby and ALSuhaibani (2001) noted that operational, economic, and field conditions can predict predict repair and maintenance costs than general models.

Table 2 shows that of the harrow with the theoretical efficiency of ranging between $80 \%$ - 95\% with an average of $71 \%$ while the actual efficiency was between $17 \%-45 \%$ with an average of $22 \%$. The width of cut ranges between $1.30 \mathrm{~m}-2.20 \mathrm{~m}$ with an average of $1.79 \mathrm{~m}$. The operation speed range between 14.0 $\mathrm{km} / \mathrm{hr}-16.0 \mathrm{~km} / \mathrm{hr}$ with an average of 15.0 $\mathrm{km} / \mathrm{hr}$. The operating hour/day is about $8.0 \mathrm{hrs}$. The average field capacity (ha/hr) is between $1.82 \mathrm{ha} / \mathrm{hr}-4.50 \mathrm{ha} / \mathrm{hr}$ is between $(0.68-0.87) \mathrm{ha} / \mathrm{hr}$ with an average of $0.60 \mathrm{ha} / \mathrm{hr}$. Table 5 reveal that field theoretical efficiency of the ridger is between $(80-90) \%$ with an average of $71 \%$ while the actual field is between (41$81) \%$ with an average of $47 \%$. The speed ranges between $9.0 \mathrm{~km} / \mathrm{hr}-10.5 \mathrm{~km} / \mathrm{hr}$, working hour per day is about $8.0 \mathrm{hr}$ and the width of cut ranges between $0.50 \mathrm{~m}-$ $0.9 \mathrm{~m}$ with an average of $0.55 \mathrm{~m}$. The theoretical field capacity is between 0.88 $1.64 \mathrm{ha} / \mathrm{hr}$ with an average of $1.07 \mathrm{ha} / \mathrm{hr}$ while the effective capacities ranges between $0.68 \mathrm{ha} / \mathrm{hr}-0.87 \mathrm{ha} / \mathrm{hr}$ with an average of $0.60 \mathrm{ha} / \mathrm{hr}$. The nature of the terrain, the soil condition and vegetation in Osun State affects its efficiency as most of implement are designed to suite the working condition of the temperate region but not tropics. 


\section{Reliability Function}

The records of time between failure or breakdown and repairs are obtained from the field evaluation and staff logbooks were analyzed to obtain the weibull scale parameter $(\alpha)$ and shape parameter $(\beta)$. Reliability R (t) can assume values between 0 and 1 , the time between failures at which the equipment will have $50 \%$ or 0.5 reliability was calculated using weibull model. Thus the time between failures at $50 \%$ reliability from its general function is
$\mathrm{t}_{50}=\alpha[-\operatorname{Ln}(0.5)]^{1 / \beta}$

The significance of the time between failures at $50 \%$ reliability $\left(\mathrm{t}_{50}\right)$ is that it is the time between failures at which each components or implement has a 50-50\% chances failure. This implies that factors highlighted by Inns (1978) on operational aspects of tractor use in developing are critical in machine availability and maintenance.

Table 1: Performance evaluation of the ploughs

\begin{tabular}{|c|c|c|c|c|c|c|c|c|c|}
\hline $\mathrm{S} / \mathrm{N}$ & $\mathrm{N}$ & $\begin{array}{l}\text { speed } \\
\mathrm{km} / \mathrm{hr}\end{array}$ & $\begin{array}{l}\text { (m) } \\
\text { width }\end{array}$ & $\begin{array}{l}\mathrm{C}_{\mathrm{T}} \\
\text { (ha/hr) }\end{array}$ & $\begin{array}{l}\mathrm{C}_{\mathrm{E}} \\
\text { (ha/dy) }\end{array}$ & $\begin{array}{c}\mathrm{C}_{\mathrm{E}} \\
\text { (ha/hr) }\end{array}$ & $\begin{array}{l}\text { Working } \\
\text { Period }(\mathrm{hr})\end{array}$ & $\eta_{\mathrm{FT}}$ & $\eta_{\mathrm{FA}}$ \\
\hline 1 & 3 & 10.0 & 0.27 & 0.81 & 3.40 & 0.38 & 9.0 & 0.90 & 0.47 \\
\hline 2 & 3 & 10.0 & 0.25 & 0.75 & 3.30 & 0.41 & 8.0 & 0.90 & 0.55 \\
\hline 3 & 3 & 10.5 & 0.24 & 0.76 & 3.20 & 0.40 & 8.0 & 0.84 & 0.53 \\
\hline 4 & 3 & 10.0 & 0.26 & 0.78 & 3.20 & 0.40 & 8.0 & 0.85 & 0.51 \\
\hline 5 & 3 & 9.5 & 0.30 & 0.86 & 3.00 & 0.38 & 8.0 & 0.79 & 0.44 \\
\hline 6 & 3 & 9.5 & 0.25 & 0.71 & 3.40 & 0.43 & 8.0 & 0.90 & 0.61 \\
\hline 7 & 3 & 10.0 & 0.25 & 0.75 & 3.40 & 0.49 & 7.0 & 0.90 & 0.65 \\
\hline 8 & 3 & 9.0 & 0.25 & 0.68 & 3.40 & 0.43 & 8.0 & 0.90 & 0.63 \\
\hline 9 & 3 & 10.0 & 0.30 & 0.90 & 3.40 & 0.43 & 8.0 & 0.90 & 0.48 \\
\hline 10 & 3 & 10.0 & 0.40 & 1.20 & 3.30 & 0.41 & 8.0 & 0.87 & 0.34 \\
\hline 11 & 3 & 10.0 & 0.29 & 0.87 & 3.40 & 0.43 & 8.0 & 0.90 & 0.49 \\
\hline 12 & 3 & 10.0 & 0.50 & 1.50 & 3.50 & 0.44 & 8.0 & 0.92 & 0.29 \\
\hline 13 & 3 & 10.0 & 0.50 & 1.50 & 3.40 & 0.43 & 8.0 & 0.90 & 0.29 \\
\hline 14 & 3 & 10.0 & 0.35 & 1.05 & 3.02 & 0.38 & 8.0 & 0.80 & 0.36 \\
\hline \multicolumn{2}{|l|}{15} & 9.5 & 0.50 & 1.43 & 3.21 & 0.40 & 8.0 & 0.85 & 0.28 \\
\hline \multicolumn{2}{|c|}{ Total } & 148 & 4.91 & 14.55 & 49.53 & 6.24 & & 13.12 & 6.92 \\
\hline \multicolumn{2}{|c|}{ Average } & 9.87 & 0.33 & 0.97 & 3.30 & 0.42 & & 0.88 & 0.46 \\
\hline \multicolumn{10}{|c|}{$\mathrm{C}_{\mathrm{T}} \quad=$ field capacity $=(\mathrm{n} \times$ speed $\mathrm{x}$ width $) / 10$} \\
\hline \multirow{2}{*}{\multicolumn{10}{|c|}{$\begin{array}{ll}\mathrm{n} & =\text { number of disc } \\
\mathrm{C}_{\mathrm{E}} & =\text { effective filed }\end{array}$}} \\
\hline & & & & & & & & & \\
\hline \multicolumn{10}{|c|}{$\eta_{\mathrm{FT}} \quad=$ Theore } \\
\hline \multicolumn{10}{|l|}{$\eta_{\mathrm{FA}}$} \\
\hline
\end{tabular}


Table 2: Performance evaluation of Harrows

\begin{tabular}{llllllllll}
\hline S/N & $\mathrm{n}$ & $\begin{array}{l}(\mathrm{m}) \\
\text { width }\end{array}$ & $\begin{array}{l}\text { Speed } \\
\mathrm{km} / \mathrm{hr}\end{array}$ & $\begin{array}{l}\text { Working } \\
\text { Period } \\
(\mathrm{hr})\end{array}$ & $\begin{array}{l}\mathrm{C}_{\mathrm{T}} \\
(\mathrm{ha} / \mathrm{hr})\end{array}$ & $\begin{array}{l}\mathrm{C}_{\mathrm{E}} \\
(\mathrm{ha} / \mathrm{dy})\end{array}$ & $\begin{array}{l}\mathrm{C}_{\mathrm{E}} \\
(\mathrm{ha} / \mathrm{hr})\end{array}$ & $\eta_{\mathrm{FT}}$ & $\eta_{\mathrm{FA}}$ \\
\hline 1 & 18 & 1.80 & 15.0 & 9.0 & 2.70 & 6.12 & 0.68 & 0.90 & 0.25 \\
2 & 18 & 1.40 & 16.0 & 8.0 & 2.24 & 5.98 & 0.75 & 0.88 & 0.33 \\
3 & 18 & 1.80 & 15.0 & 8.0 & 2.70 & - & - & - & - \\
4 & 18 & 1.80 & 16.0 & 8.0 & 2.88 & 6.46 & 0.81 & 0.95 & 0.28 \\
5 & 18 & 1.82 & 14.0 & 8.0 & 2.55 & 6.12 & 0.77 & 0.99 & 0.30 \\
6 & 18 & 1.30 & 14.0 & 8.0 & 1.82 & - & - & - & - \\
7 & 18 & 1.30 & 15.0 & 7.0 & 1.95 & 6.12 & 0.87 & 0.90 & 0.45 \\
8 & 18 & 1.60 & 14.0 & 8.0 & 2.24 & - & - & - & - \\
9 & 18 & 2.13 & 16.0 & 8.0 & 3.41 & 5.78 & 0.72 & 0.85 & 0.21 \\
10 & 18 & 2.00 & 15.0 & 8.0 & 4.50 & 6.12 & 0.77 & 0.90 & 0.17 \\
11 & 18 & 1.90 & 14.0 & 8.0 & 2.66 & 6.12 & 0.77 & 0.90 & 0.29 \\
12 & 18 & 2.20 & 16.0 & 8.0 & 3.52 & 5.44 & 0.68 & 0.80 & 0.19 \\
13 & 18 & 2.00 & 16.0 & 8.0 & 3.20 & 5.98 & 0.75 & 0.88 & 0.23 \\
14 & 18 & 2.00 & 150 & 8.0 & 3.00 & 585 & 0.73 & 0.86 & 0.24 \\
15 & 18 & 1.80 & 14.0 & 8.0 & 2.52 & 6.12 & 0.77 & 0.90 & 0.31 \\
\hline Total & 270 & 26.86 & 4.91 & 14.55 & 49.53 & 6.24 & 9.07 & 10.71 & 3.25 \\
\hline
\end{tabular}

Table 3: Performance evaluation of the Ridgers

\begin{tabular}{llllllllll}
\hline S/N & $\begin{array}{l}\text { Speed } \\
\mathrm{km} / \mathrm{hr}\end{array}$ & $\mathrm{N}$ & $\begin{array}{l}\text { Working } \\
\text { Period }(\mathrm{hr})\end{array}$ & $\begin{array}{l}\text { width } \\
(\mathrm{m})\end{array}$ & $\begin{array}{l}\mathrm{C}_{\mathrm{T}} \\
(\mathrm{ha} / \mathrm{hr}\end{array}$ & $\begin{array}{l}\mathrm{C}_{\mathrm{E}} \\
(\mathrm{ha} / \mathrm{dy})\end{array}$ & $\begin{array}{l}\mathrm{C}_{\mathrm{E}} \\
(\mathrm{ha} / \mathrm{hr})\end{array}$ & $\eta_{\mathrm{FT}}$ & $\eta_{\mathrm{FA}}$ \\
\hline 1 & 10.0 & 4 & 9.0 & 0.75 & 1.50 & 6.12 & 0.68 & 0.90 & 0.41 \\
2 & 10.0 & 4 & 8.0 & 0.75 & 1.50 & 6.12 & 0.77 & 0.90 & 0.51 \\
3 & 10.5 & 4 & 8.0 & 0.75 & 1.43 & 6.17 & 0.77 & 0.90 & 0.54 \\
4 & - & 4 & 8.0 & - & - & - & - & - & - \\
5 & 10.0 & 4 & 8.0 & 0.75 & 1.50 & 6.12 & 0.77 & 0.90 & 0.51 \\
6 & - & 4 & 8.0 & - & - & - & - & - & - \\
7 & 10.0 & 4 & 7.0 & 0.75 & 1.50 & 6.12 & 0.87 & 0.90 & 0.58 \\
8 & - & 4 & 8.0 & - & - & - & - & - & - \\
9 & 10.0 & 4 & 8.0 & 0.70 & 1.40 & 5.98 & 0.75 & 0.88 & 0.54 \\
10 & 8.0 & 4 & 8.0 & 0.55 & 0.88 & 5.44 & 0.68 & 0.80 & 0.77 \\
11 & 10.0 & 4 & 8.0 & 0.70 & 1.40 & 5.78 & 0.72 & 0.85 & 0.51 \\
12 & 9.5 & 4 & 8.0 & 0,50 & 0.95 & 6.12 & 0.77 & 0.90 & 0.81 \\
13 & 10.0 & 4 & 8.0 & 0.65 & 1.30 & 5.80 & 0.73 & 0.86 & 0.56 \\
14 & 9.0 & 4 & 8.0 & 0.91 & 1.64 & 6.12 & 0.77 & 0.90 & 0.47 \\
15 & 10.0 & 4 & 8.0 & 0.50 & 1.00 & 6.12 & 0.77 & 0.90 & 0.77 \\
Total & 116 & 60 & & 8.26 & 16 & 71.96 & 9.05 & 10.59 & 7.12 \\
\hline Average & 7.73 & 4 & & 0.55 & 1.07 & 4.80 & 0.60 & 0.71 & 0.47 \\
\hline
\end{tabular}

Tables 4 to 6 show various weibull parameters and time between failures at $50 \%$ reliability. For plough, saucer has the highest scale parameter and highest $50 \%$ time to failure which is $80.86,58.84$ and shape parameter of 0.86 while the hub has the least $(\alpha=7.54,650=7.07$ and $\beta=$ 5.70). The overall weibull parameter for plough are $\left(\alpha=28.49\right.$ and $\beta=6.0$ with $\mathrm{t}_{50}=$ $26.85)$. For harrow only three of the 
component fails while other shows no fault at all. The Disc Blade have the highest parameter of $\alpha=22.36$ and $\beta=8.80$ with $\mathrm{t}_{50}=21.45$ but the bearing shows the least $\alpha=11.47, \beta=9.30$ and $t_{50}=11.03$. The overall Harrow parameter is given as $\alpha=$ $22.42, \beta=8.30$ and $\mathrm{t}_{50}=21.45$

Ridger had two of the component without fault at all. The top link hitch point has the highest parameter of $\alpha=93.36, \beta=$ 5.35 and $t_{50}=87.49$. The least $\alpha$ parameter is Bearing with $\alpha=14.54, \beta=1.04$ and $\mathrm{t}_{50}$ $=10.22$. The overall Ridger parameters $\alpha=$ $24.29, \beta=6.00$ and $t_{50}=22.81$. Figure 1 shows the distribution of input data as a function of time between failures of each implement. Table 6 indicated that the top link of a Ridger is more reliable at 50\% time to failure of 87.49 months and overall reliability of Ridger at $t_{50}$ is 22.81 months. For the Harrow, the most reliable component is the Disc blade with $\mathrm{t}_{50}=$ 21.45 months and the overall implement reliability of 21.45 months. Also for the plough saucer is the most reliable components with $\mathrm{t}_{50}=58.84$ months and the overall $\mathrm{t}_{50}=26.85$ months. Taking each implement as a whole, from figures 2 and
3, Harrow is relatively more reliable than Ridger and Plough. This is because it shows low incidence of breakdown in Osun State.

\section{Conclusion}

Reliability of tillage equipment in Osun State revealed that repair and maintenance of facilities affected the reliability of the implements. Lack of genuine spare parts, few or lack of special repair and maintenance tools and improper record keeping habits, adversely influence the reliability of tillage implements.

The breakdown frequencies and time to failure of the implements were collected and analyzed using weibull method showed that harrow is the most reliable in the study area followed by ridger and the least being the plough.

Most observed failed components of the Harrow in use were bearing, disc gang and disc blade while other components show no fault. The results indicated that appropriate efforts should fund agricultural establishments in order to reduce unavailability of fund to carry out repair and maintenance in the workshop.

Table 4: Weibull parameters and time between failures at 50\% reliability of the tillage equipment Plough

\begin{tabular}{llll}
\hline Plough systems/component & $\alpha$ & $\beta$ & $\mathrm{t}_{50}$ \\
\hline Main frame & 33.90 & 4.60 & 31.30 \\
Mast & & No fault & \\
Category coupling point & 15.18 & 6.60 & 14.36 \\
Standard & 16.32 & 1.20 & 12.02 \\
Hub & 7.54 & 5.70 & 7.07 \\
Saucer & 80.86 & 0.86 & 58.84 \\
Bearing & 32.79 & 1.20 & 24.16 \\
Discs & 12.30 & 1.62 & 9.81 \\
Scrapper & 16.35 & 1.55 & 12.91 \\
Furrow wheel & 22.87 & 5.80 & 21.47 \\
Furrow wheel spring & 17.99 & 1.39 & 13.74 \\
Spacer spool & & No fault & \\
\hline Whole plough assembly & 28.49 & 6.0 & 26.85 \\
\hline
\end{tabular}


Table 5: Weibull parameters and time between failures at 50\% reliability of the tillage equipment Harrow

\begin{tabular}{llll}
\hline Harrow systems/ component & $\alpha$ & $\beta$ & $\mathrm{t}_{50}$ \\
\hline Disc blade & 22.36 & 8.80 & 21.45 \\
Disc gang & 15.60 & 1.03 & 10.93 \\
Spacer spool & & No fault & \\
Frame & & No fault & \\
Scrapper & & No fault & \\
Bearing & 11.47 & 9.30 & 11.03 \\
Leveling devices & & No fault & \\
Weight box & & No fault & \\
\hline Whole Harrow assembly & 22.42 & 8.30 & 21.45 \\
\hline
\end{tabular}

Table 6: Weibull parameters and time between failures at 50\% reliability of the tillage equipment Ridger

\begin{tabular}{llll}
\hline Ridger systems/component & $\alpha$ & $\beta$ & $\mathrm{t}_{50}$ \\
\hline Main frame & & No fault & \\
Standard & & No fault & \\
Discs & 52.85 & 9.10 & 50.76 \\
Hub & 18.26 & 6.10 & 17.20 \\
Bearing & 14.54 & 1.04 & 10.22 \\
Top link hitch point & 93.69 & 5.35 & 87.49 \\
Right lower link hitch point & 68.72 & 8.00 & 65.64 \\
Left lower link hitch & 53.52 & 1.20 & 39.43 \\
\hline Whole ridger assembly & 24.29 & 6.00 & 22.81 \\
\hline
\end{tabular}




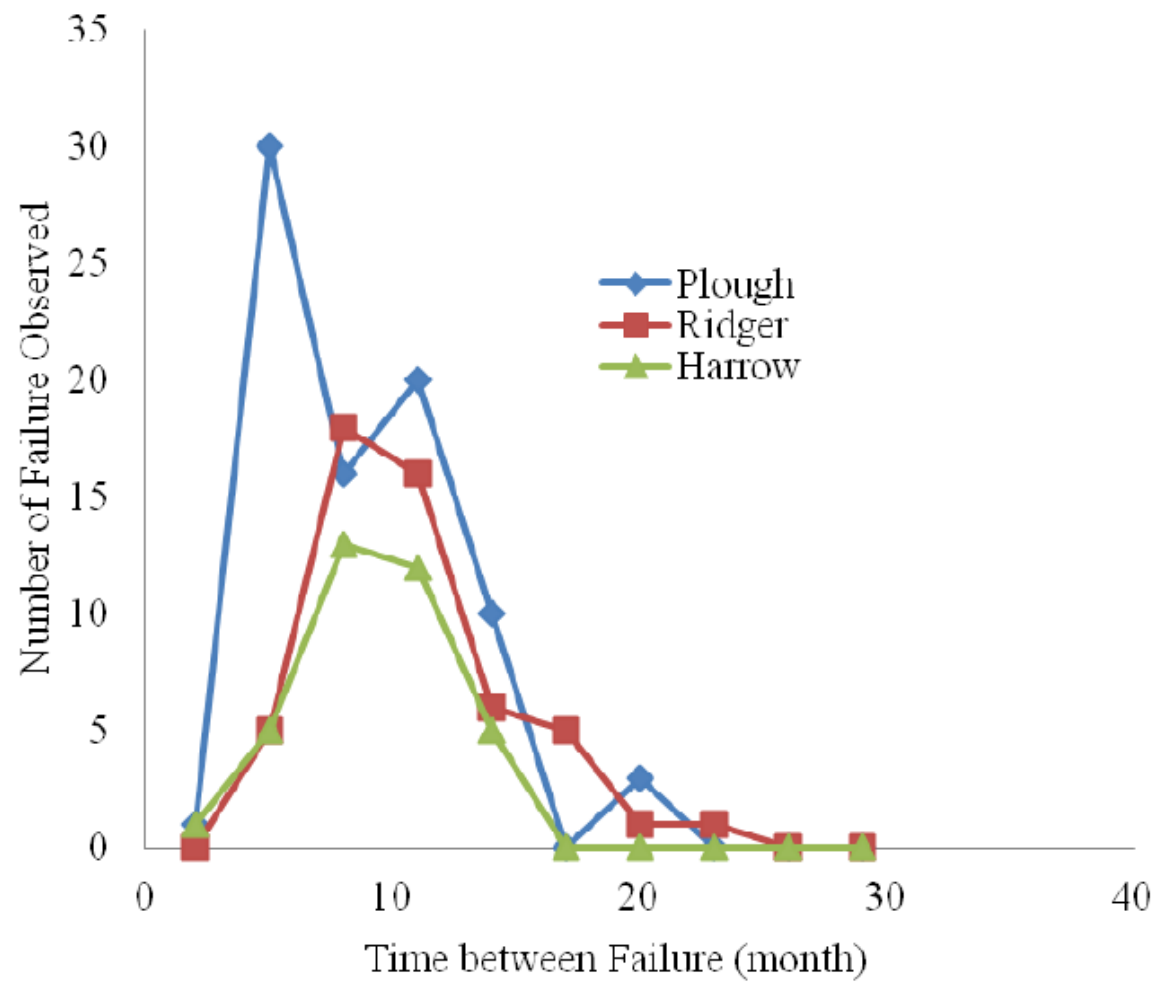

Figure 1: Distribution of Time between Failure of Plough, Ridger and Harrow

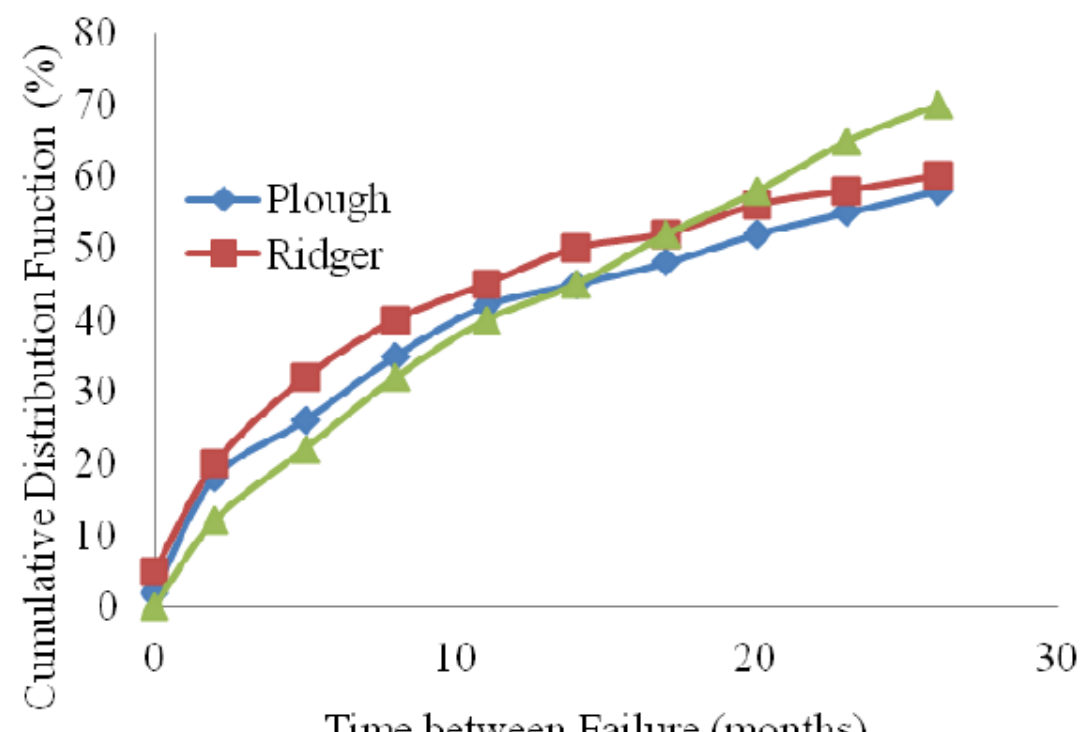

Time between Failure (months)

Figure 2: Cumulative Distribution Function of the Implements 


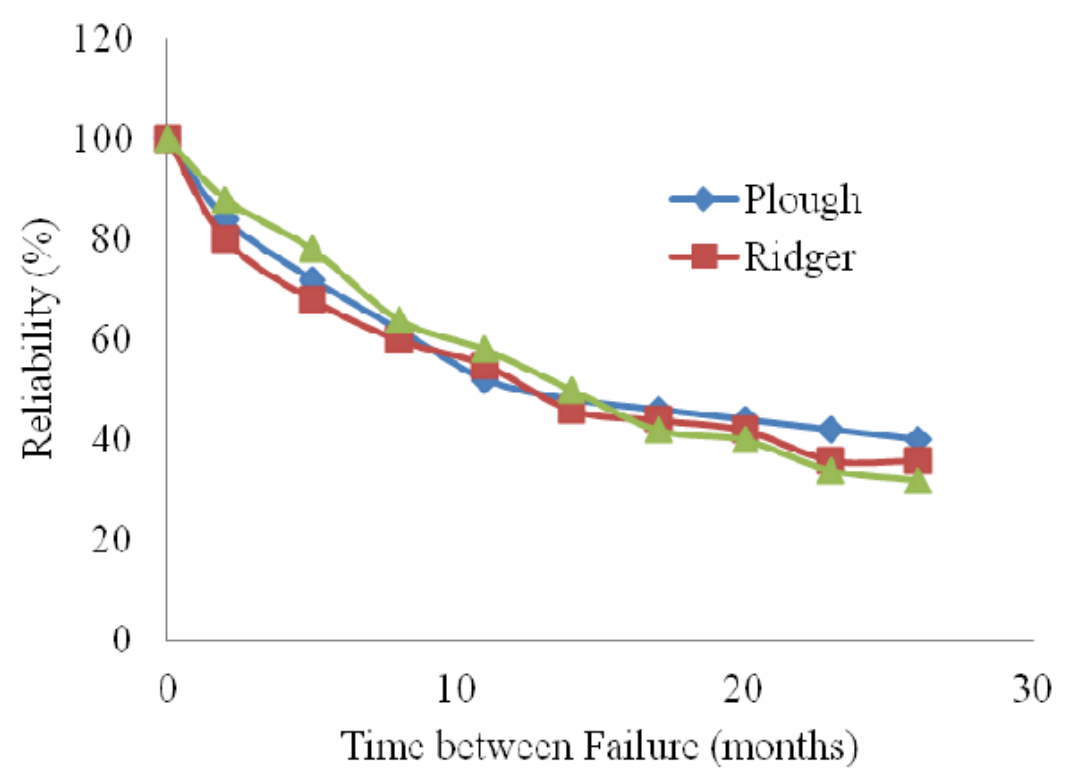

Figure 3: Reliability Function of the Implements

\section{Acknowledgement}

The authors acknowledge Mr. Babatunde for his participation and data generated from a special project Assigned to him.

\section{References}

Abdelmotaleb, I.A. (1993). Repair and Maintenance Costs Analysis of Farm Machines under Egypt's Conditions. Misr Journal of Agricultural Engineering, Proceeding of the International Conference on Technological Techniques for Handling Agricultural Products, Faculty of Agriculture, Cairo University, pp.22.

AL-Suhaibani， S.A. (1996). Multi-linear Repair and Maintenance Cost Models for Tractors in Saudi Arabia. The Journal of King Saud University (Agricultural sciences), 8(2): 247259.

Archer, R.C (1963). Reliability Engineering and its Application to farm Equipment, Agricultural Engineering Journal, 44: 542 - 547.

Dhudsia, V. (1992). Guidelines for Equipment Reliability Technology Transfer \# 92031014A-GEN, SEMATECH. $162 \mathrm{pp}$.

Hartman, S.E.H. (1983). Current and future trends in Tillage in the Humid and sub-humid Tropics. Conference paper 1.20-22 April, 1983.

Hunt D. (1971). Equipment reliability, Indiana and Illinois Data. Transaction American Society of Agricultural Engineers. 14 (5):742 746.

Inns, F.M. (1978). Operational Aspects of Tractor Use in Developing Countries - A Case for the Small Tractor. The Agricultural Engineer, Summer 1978, 52-54.

Ishola. T.A, and Adeoti, J.S. (2004). A study of farm tractors Reliability in Kwara State of Nigerian. Proceeding of the NIAE $5^{\text {th }}$ international 
conference and $26^{\text {th }}$ Annual general meeting held at Ilorin. Pg $98-107$.

Kapur, K.C and Lamberson, LR. (1977). Reliability in engineering design. John Wiley and Sons Publishers.

Konda, I. and Larson, D.L. (1990). Tractor Repair and Maintenance Costs and Management Policies in Burkina Faso. ASAE Paper No. 90-8503.

Kumar, C.P. and Mittal, S. (2008). Soil Moisture Retention Characteristics and Hydraulic Conductivity for Different Areas in India in Selected States. Journal of Soil and Water Conservation, Soil Conservation Society of India 7(2): 41 - 45.

Lal, R. (1987) important of tillage system in soil and water management in the tropics, soil tillage and crop production. IITA.Proceeding series No 2.Pp. 25 - 32 ITIA Ibadan Nigeria.

Lal, R. (1997). Long - Term Tillage and Maize Monoculture Effects on a Tropical Alfisol in Western Nigeria. I. Crop Yield and Soil Physical Properties. Soil and Tillage Res., 42: $145-160$

National Population Commission. (2010). Federal Republic of Nigeria 2006 Population and Housing Census Priority Table. Population Distribution by Sex and Types of Household (State \& Local Government Area). Volume VIII. www.population.gov.ng.

Ofori, C.S (1995). Towards the development and technology transfer of soil management practices for increased Agricultural in Africa. In: Alienkarah, Y., Owusubennoal E and Dowuora G.N.N (eds) seminar: sustaining soil production intensive Africa Agriculture, Accra, Ghana 1519 Nov, 199

Okah-Avae, B.E. (1996) The science of industrial machinery and systems maintenance, $2^{\text {nd }}$ Edition, Spectrum books limited Ibadan Nigeria.

Olaoye, J.O. (2007). An evaluation of farm power and equipment ownership and management in Niger State, Nigeria. Nigeria Journal of Technological Development (NJTD), 5(2): $94-102$.

Rotz, C. A. 1987. A Standard Model for Repair Costs of Agricultural Machinery. Applied Engineering in Agriculture, 3(1): 3-9.

Rutter, C. (2009). Equipment Reliability Made Visual: Effective Labeling Enhances Asset Performance. Brady Worldwide, Inc. www.bradyid.com/visualworkplace 1-888-250-3089. Accessed on 2/8/2010.

Wahby, M.F. and AL-Suhaibani, S.A. (2001). Repair and Maintenance Cost Models for Agricultural Equipment in Saudi Arabia. Paper No. 011027 An ASAE Meeting Presentation. 2001 ASAE Annual International Meeting Sacramento, California, USA. July 29-August, 2001.

Wingate-Hill, R. (1981). The Application of Reliability Engineering to Farm Machinery. Journal of Agricultural Engineering Winter edition. Trans of ASAE pg $109-111$. 